\title{
The optical properties and in-situ observational evidence for the formation of brown carbon in cloud
}

Ziyong Guo ${ }^{1,2,3}$, Yuxiang Yang ${ }^{1,2,3}$, Xiaodong $\mathrm{Hu}^{1,2,3}$, Xiaocong Peng ${ }^{1,2,3}$, Yuzhen $\mathrm{Fu}^{1,2,3}$, Wei Sun ${ }^{1,2,3}$, Guohua Zhang ${ }^{1,3,4}$, Duohong Chen ${ }^{5}$, Xinhui $\mathrm{Bi}^{1,3,4}$, Xinming Wang ${ }^{1,3,4}$, Ping'an Peng ${ }^{1,3,4}$

${ }^{1}$ State Key Laboratory of Organic Geochemistry and Guangdong Key Laboratory of Environmental Protection and Resources Utilization, Guangzhou Institute of Geochemistry, Chinese Academy of Sciences, Guangzhou 510640, PR China

${ }^{2}$ University of Chinese Academy of Sciences, Beijing 100049, PR China

${ }^{3}$ CAS Center for Excellence in Deep Earth Science, Guangzhou, 510640, China

${ }^{4}$ Guangdong-Hong Kong-Macao Joint Laboratory for Environmental Pollution and Control, Guangzhou Institute of 10 Geochemistry, Chinese Academy of Sciences, Guangzhou 510640, PR China

${ }^{5}$ State Environmental Protection Key Laboratory of Regional Air Quality Monitoring, Guangdong Environmental Monitoring Center, Guangzhou 510308, P. R. China

Correspondence to: Guohua Zhang (zhanggh@gig.ac.cn)

Abstract. Atmospheric brown carbon $(\mathrm{BrC})$ makes a substantial contribution to aerosol light-absorbing and thus the global radiative forcing. Although $\mathrm{BrC}$ may change the lifetime of the cloud and ultimately affect precipitation, little is known regarding the optical properties and formation of $\mathrm{BrC}$ in the cloud. In the present study, the light-absorption properties of cloud droplet residual (cloud RES) were measured by coupled a ground-based counterflow virtual impactor (GCVI) and an Aethalometer (AE-33), in addition to the cloud interstitial (cloud INT) and ambient (cloud-free) particles by PM$_{2.5}$ inlet-AE33, at Mt. Tianjing (1690 m a.s.1.), a remote mountain site in southern China, from November to December 2020. Meanwhile, the light-absorption and fluorescence properties of water-soluble organic carbon (WSOC) in the collected cloud water and $\mathrm{PM}_{2.5}$ samples were also obtained, associated with the concentration of water-soluble ions. The mean light-absorption coefficient $\left(\mathrm{Abs}_{370}\right)$ of the cloud RES, cloud INT, and cloud-free particles were $0.25 \pm 0.15,1.16 \pm 1.14$, and $1.47 \pm 1.23 \mathrm{Mm}^{-}$ ${ }^{1}$, respectively. The $\mathrm{Abs}_{365}$ of WSOC was $0.11 \pm 0.08 \mathrm{Mm}^{-1}$ in cloud water and $0.40 \pm 0.31 \mathrm{Mm}^{-1}$ in $\mathrm{PM}_{2.5}$, and the corresponding mass absorption efficiency $\left(\mathrm{MAE}_{365}\right.$ ) was $0.17 \pm 0.07$ and $0.31 \pm 0.21 \mathrm{~m}^{2} \cdot \mathrm{g}^{-1}$, respectively. A comparison of the light-absorption coefficient between $\mathrm{BrC}$ in the cloud RES/cloud INT and WSOC in cloud water/PM 2.5 indicates a considerable contribution (48-75\%) of water-insoluble $\mathrm{BrC}$ to total $\mathrm{BrC}$ light-absorption. Secondary $\mathrm{BrC}$ estimated by minimum $R$ squared (MRS) method dominated the total BrC in cloud RES (67-85\%), rather than in the cloud-free (11-16\%) and cloud INT (9-23\%) particles. It may indicate the formation of secondary $\mathrm{BrC}$ during cloud processing. Supporting evidence includes the enhanced WSOC and dominant contribution of secondary formation/biomass burning factor (> 80\%) to $\mathrm{Abs}_{365}$ in cloud water provided by Positive Matrix Factorization (PMF) analysis. In addition, we showed that the light-absorption of BrC in cloud water was closely related to humic-like substances and tyrosine/proteins-like substances ( $r>0.63, p<0.01$ ), whereas only humic-like substances for $\mathrm{PM}_{2.5}$, as identified by excitation-emission matrix fluorescence spectroscopy. 
https://doi.org/10.5194/acp-2021-945

Preprint. Discussion started: 25 November 2021

(C) Author(s) 2021. CC BY 4.0 License.

(c) (i)

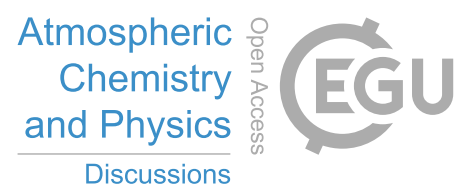

Keywords: brown carbon, light-absorption, cloud water, in-cloud process, cloud residuals 
https://doi.org/10.5194/acp-2021-945

Preprint. Discussion started: 25 November 2021

(c) Author(s) 2021. CC BY 4.0 License.

(c) (i)

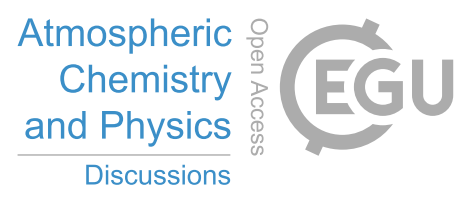

\section{$35 \quad$ Key points}

- The optical properties of $\mathrm{BrC}$ in both cloud-processed and cloud-free particles were simultaneously obtained.

- In-cloud process may facilitate the formation of $\mathrm{BrC}$, with secondary $\mathrm{BrC}$ as the dominant fraction (67-85\%).

- light-absorption of $\mathrm{BrC}$ in cloud water is closely related to humic-like and tyrosine/proteins-like substances. 


\section{Introduction}

40 Brown carbon $(\mathrm{BrC})$ makes a significant contribution to global radiative forcing, equivalent to $27-70 \%$ of that from black carbon (BC) (Lin et al., 2014a). The addition of $\mathrm{BrC}$ in climate models may change the direct radiation effect of organic aerosols from cooling $\left(-0.08 \mathrm{~W} \cdot \mathrm{m}^{-2}\right)$ to warming $\left(+0.025 \mathrm{~W} \cdot \mathrm{m}^{-2}\right)$, which may affect the lifetime and distribution of clouds, and thus precipitation and surface temperature (Zhuang et al., 2010). BrC may also contribute to uncertainties in global radiative forcing, as estimated to cause positive radiative forcing $\left(-2.0 \sim+2.5 \mathrm{~W} \cdot \mathrm{m}^{-2}\right.$, with an average of $\left.0.01 \pm 0.04 \mathrm{~W} \cdot \mathrm{m}^{-2}\right)$ in aerosolcloud interaction (Brown et al., 2018). However, such models rarely considered the secondary BrC, although increasing evidence shows that secondary BrC may represent the dominant fraction of total BrC (19-91\%) (Wang et al., 2019a, 2019b). Aqueous-phase reactions in the cloud have been shown to significantly affect global secondary organic aerosol (SOA) production (Ervens, 2015; Liu et al., 2012; Spracklen et al., 2011), and thus may potentially contribute to secondary BrC. Production of $\mathrm{BrC}$ from aqueous-phase reactions have been extensively investigated in the laboratory, revealing that $\mathrm{BrC}$ can also be secondarily formed through a variety of mechanisms, e.g., photochemical oxidation, nitration, and Maillard reactions (Lin et al., 2014b; Pósfai et al., 2004; Shapiro et al., 2009). For instance, secondary BrC is observed from the photo-oxidation of aromatics (Pang et al., 2019; Yang et al., 2021a), the nitration of phenol (Heal et al., 2007; Vione et al., 2001), and the reaction of carbonyls and ammonium/amines (De Haan et al., 2011; Nguyen et al., 2012; Heal et al., 2007). These lightabsorption species such as nitrophenols, aromatic carbonyls, imidazole, and organosulfates have also been detected in cloud/fog water (Desyaterik et al., 2013; Kim et al., 2019; Pratt et al., 2013; Bianco et al., 2016a; Lebedev et al., 2018; Lüttke and Levsen, 1997). However, to what extent do in-cloud processes contribute to the formation of $\mathrm{BrC}$ is still unclear.

Given that the currently applied imaginary refractive index of $\mathrm{BrC}$ based on the empirical formula of BC/OA ratio (Saleh et al., 2014) in the model simulation (Brown et al., 2018) may induce potential bias (Bikkina and Sarin, 2019), more field studies should be conducted to constrain the optical properties of $\mathrm{BrC}$. Although various light-absorbing species have been identified in cloud, only few studies focused on the optical properties of $\mathrm{BrC}$ in fog/cloud. Nitrophenols and aromatic carbonyls were the major fraction contributing to the light-absorption ( $50 \%)$ of cloud water at wavelengths from 300 to $400 \mathrm{~nm}$ in Mt. Tai (Desyaterik et al., 2013). The mass absorption efficiency ( $\mathrm{MAE}_{365}$ ) of water-soluble organic carbon (WSOC) in fog water in California was 0.1-0.6 $\mathrm{m}^{2} \cdot \mathrm{g}^{-1}$ (Kaur and Anastasio, 2017). The fluorescent chromophores of fog/cloud water, as identified by excitation-emission matrix fluorescence spectroscopy (EEMs) in Louisiana and Mt. Tai, were mainly composed of humic-like and protein-like substances (Birdwell and Valsaraj, 2010; Zhao et al., 2019), which might also be related to the presence of $\mathrm{BrC}$ (Chen et al., 2016; Wang et al., 2020a). However, such studies were generally limited to $\mathrm{PM}_{2.5}$, rather than in the cloud. Our previous studies have shown that the in-cloud aqueous-phase reactions could significantly promote the formation of SOA such as nitrogen-containing organic matters and affect the physicochemical properties of particles (Fu et al., 2020; Lian et al., 2021; Lin et al., 2017; Zhang et al., 2017a). In the present study, we took a further step to perform simultaneous on-line measurements of the light-absorption coefficients for the cloud droplet residual (cloud RES), cloud interstitial (cloud INT), and ambient (cloud-free) particles, coupled with the light-absorption and concentration measurements of WSOC in cloud water 
and $\mathrm{PM}_{2.5}$. We aim to explore: 1) the optical properties of $\mathrm{BrC}$ in cloud-processed, cloud-free particles and WSOC in $\mathrm{PM}_{2.5}$ and cloud water; 2) the possible contribution of in-cloud production to $\mathrm{BrC}$ light-absorption, and 3) the characteristics of fluorescent chromophores in cloud water and $\mathrm{PM}_{2.5}$ and their relationship with light-absorption properties of $\mathrm{BrC}$.

\section{$75 \quad 2$ Methods}

\subsection{Sampling setup}

Measurements of the cloud-free, cloud RES, and cloud INT particles were performed at Mt. Tianjing $\left(24^{\circ} 41^{\prime} 56^{\prime \prime} \mathrm{N}\right.$, $112^{\circ} 53^{\prime} 56^{\prime \prime} \mathrm{E}, 1690 \mathrm{~m}$ a.s.1.) in Guangdong province, China during 18 November to 5 December 2020. This site is located at a national forest reserve and is less affected by anthropogenic sources. The cloud event determination threshold was set as visibility less than $3 \mathrm{~km}$ and relative humidity (RH) larger than 95\%. During the cloud events, the cloud RES and cloud INT particles were alternately introduced into the instruments through ground-based counterflow virtual impactor (GCVI, model 1205, Brechtel Mfg., Inc., USA) and $\mathrm{PM}_{2.5}$ cutoff, respectively, at a frequency of one hour. The GCVI cut size was set to 7.5 $\mu \mathrm{m}$, where the transmission efficiency of cloud droplets is 50\% (Shingler et al., 2012). The collected cloud droplets passed through an evaporation chamber $\left(40^{\circ} \mathrm{C}\right)$, resulting in the cloud RES particles for downstream analysis. An Aethalometer (model AE-33, Magee Scientific., USA) was used to measure the light-absorption coefficients of particles at wavelengths of $370,470,520,590,660,880$, and $950 \mathrm{~nm}$. AE-33 uses two parallel spot measurement technology to compensate for the light attenuation due to the filter loading effect (Drinovec et al., 2015). The BC concentration was calculated by the light-absorption coefficient at $880 \mathrm{~nm}$. The detection limit of BC is less than $10 \mathrm{ng} \cdot \mathrm{m}^{-3}$ (equal to $0.077 \mathrm{Mm}^{-1}$ at $880 \mathrm{~nm}$ ) and the uncertainty is $\sim 2 \mathrm{ng} \cdot \mathrm{m}^{-3}$ (equal to $0.015 \mathrm{Mm}^{-1}$ at $880 \mathrm{~nm}$ ), with a time resolution of 1 minute.

Cloud water samples were collected by a Caltech Active Strand Cloud water Collector, Version 2 (CASCC2) (Demoz et al., 1996; Yang et al., 2021b) when the visibility was less than $200 \mathrm{~m}$ (during 14 November to 4 December 2020). The collection efficiency was $50 \%$ at a cut size of $3.5 \mu \mathrm{m}$. During the sampling period, 53 cloud water samples were collected. The $0.22 \mu \mathrm{m}$ quartz fiber filter was used immediately to remove insoluble components after collection of cloud water and then frozen at $20^{\circ} \mathrm{C}$ until analysis. Meanwhile, $\mathrm{PM}_{2.5}$ samples were collected by a mid-volume $\left(300 \mathrm{~L} \cdot \mathrm{min}^{-1}\right)$ aerosol sampler (PM-PUF-300,

95 Mingye, China). Daily samples (during 14 November to 8 December 2020) were collected on the quartz fiber filters, which were prebaked at $450^{\circ} \mathrm{C}$ for $4 \mathrm{~h}$ in a muffle furnace to remove residual organics before use. After collection, all samples were frozen at $-20^{\circ} \mathrm{C}$ until analysis. In this study, $\mathrm{PM}_{2.5}$ samples collected at the same time with cloud water samples were regarded as INT-PM $2.5(n=13)$, and the others as FREE-PM $2.5(n=19)$. It should be noted that some FREE-PM 2.5 samples also experienced short cloud events during collection. Blank samples of the cloud water and $\mathrm{PM}_{2.5}$ were collected and processed following the same procedure as the samples.

\subsection{Calculation of secondary BrC light-absorption}


The light-absorption coefficient $\left(\operatorname{Abs}_{\mathrm{BrC}}(\lambda), \mathrm{Mm}^{-1}\right)$ of $\mathrm{BrC}$ in different wavelengths can be obtained by $\mathrm{AE}-33$, assuming that the absorption Ångström exponent (AAE) of BC is 1 and the light-absorption at $880 \mathrm{~nm}$ only due to BC (Drinovec et al., 2015). The cloud RES, cloud INT, and cloud-free particles were generally located in submicron size (Fig. S1), and thus unlikely originated from non-combustion sources are mostly biogenic and mainly exist in the coarse mode (Perrino and Marcovecchio, 2016). The $\operatorname{Abs}_{\mathrm{BrC}}(\lambda)$ contributed by the combustion sources can be estimated through a BC-tracer method (Wu et al., 2018):

$$
A b s_{p r i, c o m b}(\lambda)=\left(\frac{A b s(\lambda)}{B C}\right)_{p r i} \times[B C]
$$

Where $\operatorname{Abs}(\lambda)$ is the total light-absorption coefficient of carbonaceous aerosol that measured by AE-33, $\left(\frac{A b s(\lambda)}{B C}\right)_{p r i}$ can be determined by the minimum $R$ squared (MRS) method to further evaluate the relative contribution of primary $\operatorname{BrC}$ and secondary formation $\operatorname{BrC}$ to the overall $\operatorname{Abs}_{\operatorname{BrC}}(\lambda)$. Firstly, $A b s_{\text {pri,comb }}(\lambda)$ is calculated based on $\left(\frac{A b s(\lambda)}{B C}\right)_{\text {pri }}$, which is assumed to be step increasing from 0 to 120 with a rate of 0.1 . The target $\left(\frac{A b s(\lambda)}{B C}\right)_{p r i}$ value can be retrieved when the correlation coefficient $\left(\mathrm{R}^{2}\right)$ between $\mathrm{Abs}_{\mathrm{BrC}, \sec }(\lambda)$ with BC concentration reaches the minimum (see Fig. S2). Previous studies showed that the bias of MRS method is less than 23\%, when the measurement uncertainty is less than $20 \%$ (Wu and Yu, 2016). It should be noted that when the measured ratio of $\frac{A b s(\lambda)}{B C}$ is lower than the retrieved $\left(\frac{A b s(\lambda)}{B C}\right)_{\text {pri }}$, the $\operatorname{Abs}_{\mathrm{BrC}, \sec }(\lambda)$ could be negative. In 115 these cases, $\operatorname{Abs}_{\mathrm{BrC}, \mathrm{sec}}(\lambda)$ is set to zero for subsequent analysis (Kaskaoutis et al., 2021; Wang et al., 2019a). These cases account for less than $5 \%$ in the cloud RES and $28-70 \%$ in the cloud INT and cloud-free particles

\subsection{Measurements of $\mathrm{PM}_{2.5}$ and cloud water}

$\mathrm{PM}_{2.5}$ samples were ultra-sonically extracted with ultrapure water (resistivity: $18.2 \mathrm{M} \Omega \mathrm{cm}$ ) for $30 \mathrm{~min}$, then filtered by the $0.22 \mu \mathrm{m}$ polytetrafluoroethylene (PTFE) filters to obtain the $\mathrm{PM}_{2.5}$ aqueous extract. The concentrations of water-soluble ions, water-soluble heavy metals, WSOC in $\mathrm{PM}_{2.5}$ aqueous extract and cloud water samples were analyzed by ion chromatography (Metrohm 883 IC plus, Switzerland), inductively coupled plasma mass spectrometry (ICP-MS, Thermo Fisher, USA), and total organic carbon analyzer (TOC-V, Shimadzu, Japan), respectively. Parallel analyses showed that the relative standard deviation of each analysis was generally less than $15 \%$. The reported concentration data herein was after blank subtraction. The light-absorption coefficient ( $\mathrm{Abs}_{\mathrm{wSOC}, \lambda}$ ) of WSOC can be obtained (Hecobian et al., 2010) by the measurement of cloud water and $\mathrm{PM}_{2.5}$ aqueous extract, with UV-Vis (UV1901, Kejie, China):

$$
A b s_{W S O C, \lambda}=\left(A_{\lambda}-A_{700}\right) \times \frac{V_{l}}{V_{a} \times L} \times \ln (10)
$$

Where $A_{\lambda}$ is the absorbance of the sample, $A_{700}$ is used to account for any drift; $V_{1}$ is the volume of ultrapure water used to extract the sample (for cloud water it is the total sample volume), $V_{\mathrm{a}}$ is the volume of sampled air through the PTFE filter (for cloud water it is the total volume of sampled air), and $L$ is the cuvette path length $(0.01 \mathrm{~m})$.

130 The AAE values describing the spectral dependence of WSOC light-absorption can be further deduced by exponential fitting Abswsoc,$\lambda$ between $300-500 \mathrm{~nm}$. The MAE ${ }_{W S O c}, \lambda$ can be calculated by divided Abswsoc,,$\lambda$ by the mass concentration of WSOC 
$\left(\mu \mathrm{g} \cdot \mathrm{m}^{-3}\right.$ ). The $\mathrm{E}_{250} / \mathrm{E}_{365}$ (the ratio of absorbance at $250 \mathrm{~nm}$ to that at $365 \mathrm{~nm}$ ) is used to describe the humification of organic matter, which is inversely related to aromaticity and molecular weight of WSOC (Kristensen et al., 2015). Specific UV absorbance (SUVA, $\mathrm{m}^{2} \cdot \mathrm{g}^{-1}$ ) at 254 and $280 \mathrm{~nm}$ had been proved to be qualitatively related to the structural characteristics (aromaticity and molecular weight) of WSOC to a certain extent (Weishaar et al., 2003), which can be calculated using the following equation:

$$
S U V A_{254 \text { or } 280}=\frac{A}{L \times C_{\mathrm{WSOC}}}
$$

Where $A$ is the absorbance of sample at 254 or $280 \mathrm{~nm}, C_{\mathrm{WSOC}}$ is the concentration of WSOC $\left(\mathrm{mg} \cdot \mathrm{L}^{-1}\right)$.

The excitation-emission matrix fluorescence spectroscopy (EEMs) of $\mathrm{PM}_{2.5}$ extract and cloud water were measured by a fluorescence spectrophotometer (F97pro, Lengguang, China). The sample blank was deducted before analysis, and the EEMs were normalized to the Raman units (R.U.) by using the Ramen peak ( $E x=350 \mathrm{~nm}, \mathrm{Em}=365-430 \mathrm{~nm}$ ) of ultrapure water measured simultaneously with the sample (Lawaetz and Stedmon, 2009). Parallel factor (PARAFAC) analysis was performed on the acquired spectra with drEEM toolbox (version 0.3.0) based on MATLAB (Murphy et al., 2013), according to the outlier tests of PARAFAC, 6 samples with high leverage and high residual signals were removed in the modeling of PM $_{2.5}$ aqueous extract. The details for obtaining maximum fluorescence intensity $\left(\mathrm{F}_{\max }\right)$, fluorescence index (FI), recent autochthonous contribution (BIX), and humification index (HIX) were described in the supporting information (SI) text S1.

\section{Results and Discussion}

\subsection{The optical properties of $\mathrm{BrC}$ during cloud events}

The presence of $\mathrm{BrC}$ could be indicated by the AAE values derived from AE-33 data, which are $1.30 \pm 0.12$ for cloud-free, $1.36 \pm 0.22$ for cloud INT, and $1.32 \pm 0.15$ for cloud RES particles. The light-absorption coefficient of $\mathrm{BrC}$ at $370 \mathrm{~nm}\left(\mathrm{Abs}_{370}\right)$ of cloud-free, cloud INT and cloud RES particles are $1.47 \pm 1.23,1.16 \pm 1.14$, and $0.25 \pm 0.15 \mathrm{Mm}^{-1}$, respectively (Fig. 1), with the $\mathrm{AAE}$ values of $\mathrm{BrC}$ at $2.71 \pm 0.69,3.13 \pm 0.97$, and $2.76 \pm 0.89$, respectively. The contribution of BrC light-absorption to the total particle light-absorption in the cloud-free, cloud INT, and cloud RES particles shows no significant difference, on average decreasing from $\sim 23 \%$ at $370 \mathrm{~nm}$ to $\sim 7 \%$ at $660 \mathrm{~nm}$, as shown in Fig. 2.

155 For the cloud water and $\mathrm{PM}_{2.5}$ aqueous extracts, light-absorption properties of WSOC at $365 \mathrm{~nm}$ are taken as the representative to those of water-soluble $\mathrm{BrC}$ (WS-BrC) in the present study. As expected, there is a positive correlation between $\mathrm{Abs}_{365}$ and WSOC concentration in cloud water and $\mathrm{PM}_{2.5}$ aqueous extracts $(\mathrm{r}>0.61, p<0.01)$. As shown in Fig. 1, there is great difference in $\mathrm{Abs}_{365}$ of WSOC in FREE-PM 2.5 , INT-PM 2.5 , cloud water-Day, and cloud water-Night, which are $0.49 \pm 0.34,0.27 \pm 0.18$, $0.09 \pm 0.04$, and $0.13 \pm 0.10 \mathrm{Mm}^{-1}$, respectively. The $\mathrm{Abs}_{365}$ of WSOC in $\mathrm{PM}_{2.5}$ in this study is at the same magnitude to that of $\mathrm{PM}_{10}$ in Tibet Plateau (Kirillova et al., 2016), and much lower than those in urban areas (as summarized in Table S1) (Chen et al., 2018, 2020; Huang et al., 2020; Kim et al., 2016). The AAE of WSOC has no significant difference among FREE-PM 2.5 , 
INT-PM 2.5 , cloud water-Day, and cloud water-Night, which are $6.01 \pm 0.81,5.37 \pm 1.08,5.81 \pm 1.47$, and $6.31 \pm 1.51$, respectively, within the reported range.

The MAE M65 $_{36}$ of WSOC in FREE-PM 2.5 , INT-PM 2.5 , cloud water-Day, and cloud water-Night are $0.31 \pm 0.17,0.31 \pm 0.26,0.17$ \pm 0.07 , and $0.17 \pm 0.07 \mathrm{~m}^{2} \cdot \mathrm{g}^{-1}$, respectively. The MAE 365 of WSOC in cloud water and $\mathrm{PM}_{2.5}$ are much lower than those in urban/alpine areas and various source emission samples (Table S1) (Chen et al., 2018, 2020; Fan et al., 2016; Huang et al., 2020; Kim et al., 2016; Kirillova et al., 2016; Li et al., 2019; Park and Yu, 2016; Soleimanian et al., 2020; Wu et al., 2019). The MAE M65 $_{35}$ of WSOC shows no significant difference between the FREE-PM 2.5 and INT-PM 2.5 , which is similar to the result observed in the Indo-Gangetic plain (Choudhary et al., 2018), but their values are quite higher, i.e., $1.6 \mathrm{~m}^{2} \cdot \mathrm{g}^{-1}$ and $1.8 \mathrm{~m}^{2} \cdot \mathrm{g}^{-1}$ for the INT-PM ${ }_{1.0}$ and FREE-PM 1.0 , respectively. The MAE 365 of WSOC in cloud water $\left(0.06-0.32 \mathrm{~m}^{2} \cdot \mathrm{g}^{-1}\right)$ is slightly lower than the previously reported values in fog water $\left(0.1-0.6 \mathrm{~m}^{2} \cdot \mathrm{g}^{-1}\right)$ in California (Kaur and Anastasio, 2017). Both the MAE 365 of WSOC in cloud water and $\mathrm{PM}_{2.5}$ show a positive correlation $(\mathrm{r}>0.84, p<0.01)$ with $\mathrm{SUVA}_{254 / 280}$, and a medium negative correlation $(r>0.43, p<0.05)$ with $\mathrm{E}_{250} / \mathrm{E}_{365}$, which indicates that the aromaticity and molecular weight of WSOC may influence the light-absorption capacity of cloud water and $\mathrm{PM}_{2.5}$ (Fig. S3).

Although there are tight correlations between the $\mathrm{Abs}_{370}$ for cloud water and the cloud RES particles, and for the INT-PM 2.5 and the cloud INT particles (Fig. 3, $\mathrm{r}>0.60, p<0.01)$, the $\mathrm{Abs}_{370}$ of WSOC in cloud water $\left(0.12 \mathrm{Mm}^{-1}\right)$ and INT-PM $2.5(0.27$ $\left.\mathrm{Mm}^{-1}\right)$ is considerably lower than those in the cloud RES $\left(0.24 \mathrm{Mm}^{-1}\right)$ and cloud INT particles $\left(1.08 \mathrm{Mm}^{-1}\right)$ that collected simultaneously. Such difference may be attributed to the contribution of water-insoluble organic carbon (WIOC). The different optical properties for the whole $\mathrm{BrC}$ and WS-BrC may also be reflected by the $\mathrm{AAE}$ values. They are generally in a range of 4-8 at 300-500 nm in cloud water and $\mathrm{PM}_{2.5}$, much higher than those for $\mathrm{BrC}(2-4)$ calculated from AE-33 data at 370-660 nm. The contribution of water-insoluble $\mathrm{BrC}$ to the light-absorption is estimated to be $\sim 75 \%$ for the cloud INT particles and $\sim 48 \%$ for the cloud RES particles on average, based on these differences (Fig. 3). It is also noted that the light-absorption of WIOC might still be underestimated by $\sim 16 \%$ when sampling size is considered for the GCVI and cloud sampler (as discussed in SI text S1). High contributions of WIOC to BrC light-absorption have also been observed in the Indo-Gangetic plain (77\%) (Satish et al., 2020), Beijing (62\%), and Xi'an (51\%) (Huang et al., 2020).

\subsection{The secondary contribution of BrC during cloud events}

Fig. 2 shows the contribution of secondary $\mathrm{BrC}$ to the total $\mathrm{BrC}$ in cloud-free, cloud INT, and cloud RES particles estimated by the MRS method. 11-16\% and 9-23\% of the total absorption of $\mathrm{BrC}$ come from the secondary $\mathrm{BrC}$ for the cloud-free and cloud INT particles, respectively. Only a slight difference observed for the cloud-free and cloud INT particles, indicating that cloud processing may have limited influence on the cloud INT particles. It is noted that even during the cloud-free periods, RH was generally higher than $70 \%$ (Fig. S1). The contribution of secondary BrC in cloud INT and cloud-free particles are in the low range of reported values (as summarized in Table S2) (Gao et al., 2022; Kaskaoutis et al., 2021; Lin et al., 2021; Wang et al., 2019a, 2019b, 2020b, 2021; Zhang et al., 2020, 2021; Zhu et al., 2021). 
Differently, the contribution of secondary formed $\mathrm{BrC}$ to the total $\mathrm{BrC}$ light-absorption is $67-85 \%$ in the cloud RES particles, surprisingly higher than those in the cloud-free and cloud INT particles. Such a high contribution may suggest the critical role of cloud processing in the formation of $\mathrm{BrC}$. Compared with the relative contributions for the cloud-free and cloud INT particles, the importance of such a process in cloud droplets remarkably overrides that in wet particles. The significance of secondary water-soluble $\mathrm{BrC}$ formation in cloud droplets may also be reflected by the significant correlation between the $\mathrm{Abs}_{365}$ of cloud water and $\mathrm{PM}_{2.5}$ aqueous extract with SNA (sulfate, nitrate, and ammonium) $(\mathrm{r}>0.77, p<0.01)$, and NOx $(\mathrm{r}>$ $0.58, p<0.01$ ), as shown in Fig. S4. The SNA and NOx concentrations are higher at night than the daytime (Fig. S5), consistent with higher $\mathrm{Abs}_{365}$ of cloud water at night. NOx may enhance the formation of nitrogen-containing organics (Seinfeld and Pandis, 2016; Yang et al., 2021a), potentially contributing to the light-absorption of cloud water (Desyaterik et al., 2013). Incloud aqueous processes leading to more $\mathrm{CHON}$ compounds in cloud water than below-cloud atmospheric particles has also been observed (Boone et al., 2015). In addition, a comparison between the WSOM (WSOM = WSOC*1.8) normalized by $\mathrm{K}^{+}$ (as a primary source tracer) in cloud water than INT-PM 2.5 (Fig. S6) also clearly indicates the enhanced formation of WSOM in cloud water. It is consistent with that the light-absorption of WSOC contributed more to the cloud RES ( 52\%) than the cloud INT (25\%) particles, as estimated in Fig. 3.

Consistently, the source and contribution apportionment of $\mathrm{BrC}$ in cloud water (i.e., $\mathrm{Abs}_{365}$ ) evaluated by the PMF model (see SI for data analysis and evaluation methods) also supports the critical role of aqueous process on the formation of $\mathrm{BrC}$, as shown in Fig. 4. Factor 1 is associated with relatively higher $\mathrm{K}^{+}, \mathrm{NH}_{4}{ }^{+}, \mathrm{NO}_{3}{ }^{-}, \mathrm{SO}_{4}{ }^{2-}$, and $\mathrm{C}_{2} \mathrm{O}_{4}{ }^{2-}$, contributing $64.3 \%$ to WSOC and $86.9 \%$ to $\mathrm{Abs}_{365}$. It may be appropriately recognized as secondary products with contribution from biomass burning, as $\mathrm{K}^{+}$ represents a tracer for biomass burning, and $\mathrm{NH}_{4}{ }^{+}, \mathrm{NO}_{3}{ }^{-}, \mathrm{C}_{2} \mathrm{O}_{4}{ }^{2-}$, and $\mathrm{SO}_{4}{ }^{2-}$ are regarded as secondary species (Cheng et al., 2015; Wang et al., 2012). Note that $\mathrm{C}_{2} \mathrm{O}_{4}{ }^{2-}$ is generally considered as a tracer of aqueous-phase processes (Zhang et al., 2017b). As previously observed, the aqueous SOA formed from biomass burning might contributed to the $\mathrm{BrC}$ budget in fog water (Gilardoni et al., 2016). Factor 2 is characterized by high levels of crustal trace elements such as $\mathrm{Mg}^{2+}, \mathrm{Ca}^{2+}, \mathrm{Mn}$, and $\mathrm{Zn}$, and thus identified as crustal materials, contributing 21.9\% to WSOC and 8.7\% to $\mathrm{Abs}_{365}$. Factor 3 shows extremely high loading with $\mathrm{Na}^{+}$and relatively high $\mathrm{Mg}^{2+}, \mathrm{Cl}^{-}$, and $\mathrm{Ni}$, which may originate from marine, contributing $13.8 \%$ to WSOC and $4.4 \%$ to $\mathrm{Abs}_{365}$.

\subsection{Fluorescence properties of $\mathrm{BrC}$ in $\mathrm{PM}_{2.5}$ and cloud water}

220 The results from the EEMs measurements further indicate the different characteristics of WSOC/WS-BrC in $\mathrm{PM}_{2.5}$ and cloud water. Based on the PARAFAC model calculation (Fig. 5), two independent fluorescence components (P1-P2) assigned as humic-like substances are found in $\mathrm{PM}_{2.5}$, whereas four independent fluorescence components (C1-C4) assigned as humic-like substances (C1-C3) and tyrosine/protein-like substances (C4) are found in cloud water (Catalá et al., 2015; Coble, 2007). The fluorescence components of cloud water are similar to those in Mt. Tai (Zhao et al., 2019) and France (Bianco et al., 2016b),

225 where humic-like and protein-like substances are the main chromophores in cloud water. Compared with $\mathrm{PM}_{2.5}$, 
tyrosine/protein-like substances are unique to cloud water in the present study, which may be partly due to their relative enrichment in cloud water (Kristensson et al., 2010; Zhang and Anastasio, 2003).

In addition, the relative contribution of individual chromophores indicated by $\mathrm{F}_{\max }$ in $\mathrm{PM}_{2.5}$ and cloud water also exhibits different characteristics, although humic-like substances are the dominant fluorescent fraction in both $\mathrm{PM}_{2.5}$ and cloud water. The relative contribution shows no obvious difference between P1 and P2 components in $\mathrm{PM}_{2.5}\left(\mathrm{FREE}_{\mathrm{P}} \mathrm{PM}_{2.5}\right.$ and INT-PM 2.5$)$, whereas the $\mathrm{C} 3$ component contributes the largest (40.0\%) to the fluorescent intensity in cloud water. Further analysis of the relationship between the fluorescent components $\left(\mathrm{F}_{\mathrm{max}}\right)$ and the light-absorption of WSOC $\left(\mathrm{Abs}_{365}\right)$ in $\mathrm{PM}_{2.5}$ and cloud water shows significant positive correlations between $\mathrm{F}_{\max }$ of all fluorescent components with $\mathrm{Abs}_{365}(\mathrm{r}>0.63, p<0.01$, see Fig. 5). It suggests that these fluorescent components are tightly linked to the light-absorption of WSOC. The FI, BIX, and HIX of cloud water are $1.58 \pm 0.22,0.57 \pm 0.09$, and $4.99 \pm 3.83$ respectively, which indicates limited humified WSOC in cloud water, and also less affected by microorganisms and local sources (Huguet et al., 2009; McKnight et al., 2001; Zsolnay et al., 1999). Therefore, it is most likely that the organic components in cloud water may be significantly affected by in-cloud aqueous formation, consistent with the PMF results. With respect to the secondary processes, humic-like substances may be formed through Maillard reaction involving carbonyls and ammonium/amines (Bones et al., 2010; Hawkins et al., 2016), and also the photo-transformation of tyrosine (Berto et al., 2016).

\section{Conclusions and implications}

In the present study, the light-absorption properties of the cloud RES, cloud INT, and cloud-free particles were simultaneously investigated at a remote mountain site in southern China. Coupled with the measurements of light-absorption and fluorescence properties of WSOC in the collected cloud water and $\mathrm{PM}_{2.5}$, it is evident that in-cloud aqueous processing facilitates the formation of $\mathrm{BrC}$ (i.e., 67-85\% secondary BrC in cloud RES particles by MSR method). As potential contributors to lightabsorption of $\mathrm{BrC}$, only two fluorescence fractions of humic-like substances are found in $\mathrm{PM}_{2.5}$, whereas four fluorescence fractions (three types of humic-like substances and one type of tyrosine/protein-like substances) are identified in cloud water, most likely attributed to secondary production. While extensive laboratory evidence indicated the possible formation of $\mathrm{BrC}$ in aqueous phase (Hems et al., 2021), our study represents the first attempt to show the possibility under real cloud condition. The results could support a previous hydrolysis that in-cloud formation of $\mathrm{BrC}$ might contribute to the enhanced $\mathrm{BrC} / \mathrm{BC}$ in the attitude between 5-12 km (Zhang et al., 2017c). Such process might also have potential implication for the lifecycle of BrC (Liu et al., 2020).

In order to evaluate the influence of $\mathrm{BrC}$ formation in the light-absorption properties of cloud water, the imaginary part of the refractive index for cloud water was calculated according to Gelencsér et al. (2003), as detailed in the SI text S1. The average imaginary part of cloud water was $5.5 \times 10^{-8}$ at $365 \mathrm{~nm}$ (Fig. S7), $\sim 10$ times that of pure water. The imaginary part $\left(3.4 \times 10^{-8}\right.$ at $475 \mathrm{~nm})$ is a magnitude higher than previous laboratory simulation results $\left(5.2 \times 10^{-9}\right.$ at $\left.475 \mathrm{~nm}\right)$, involving 3,5-dihydroxybenzoic acid reaction with $\mathrm{FeCl}_{3}$ (Gelencsér et al., 2003). It should also be noted that it is the lowest estimation since only WSOC is included in the calculation. As previously indicated, the overall light-absorption of WIOC cannot be negligible. 
260 According to the average $\mathrm{MAE}_{550}$ and AAE of WSOC in cloud water and INT-PM 2.5 , the optical properties of BrC during cloud events could be classified as weakly absorptive $\mathrm{BrC}$ (Saleh, 2020). The measured optical properties and suggested incloud formation of $\mathrm{BrC}$ would help better understand the atmospheric evolution and the radiation forcing of $\mathrm{BrC}$.

Supplement. Supporting information includes one text (Text S1), seven figures (Fig. S1-S7), and two tables (Table S1-S3) 265 related to the manuscript.

Data availability. All the data can be obtained by contacting the corresponding author.

Author contributions. XB and GZ designed the research with input from XW and PP. ZG, XP, WS, HX and YY collected and 270 analysis samples. ZG processed data when $\mathrm{XH}$ and $\mathrm{YY}$ gave constructive discussion. ZG wrote the manuscript, and $\mathrm{XB}, \mathrm{GZ}$ and YF interpreted data and edited the manuscript. XH, XP, and WS had an active role in supporting the sampling work. All authors contributed to the discussions of the results and refinement of the manuscript.

Competing interests. The authors declare that they have no conflict of interest.

Financial support. This work was funded by the Natural Science Foundation of Guangdong Province (2019B151502022), National Natural Science Foundation of China (42077322, 42130611, and 41877307), Youth Innovation Promotion Association CAS (2021354), and Guangdong Foundation for Program of Science and Technology Research (2019B121205006 and 2020B1212060053). 


\section{References}

Berto, S., De Laurentiis, E., Tota, T., Chiavazza, E., Daniele, P. G., Minella, M., Isaia, M., Brigante, M. and Vione, D.: Properties of the humic-like material arising from the photo-transformation of 1-tyrosine, Sci. Total Environ., 545-546, 434-444, doi:10.1016/j.scitotenv.2015.12.047, 2016.

Bianco, A., Voyard, G., Deguillaume, L., Mailhot, G. and Brigante, M.: Improving the characterization of dissolved organic carbon in cloud water: Amino acids and their impact on the oxidant capacity, Sci. Rep., 6(August), 1-7, doi:10.1038/srep37420, 2016a.

Bianco, A., Passananti, M., Deguillaume, L., Mailhot, G. and Brigante, M.: Tryptophan and tryptophan-like substances in cloud water: Occurrence and photochemical fate, Atmos. Environ., 137, 53-61, doi:10.1016/j.atmosenv.2016.04.034, $2016 \mathrm{~b}$.

Bikkina, S. and Sarin, M.: Brown carbon in the continental outflow to the North Indian Ocean, Environ. Sci. Process. Impacts, 21(6), 970987, doi:10.1039/c9em00089e, 2019.

Birdwell, J. E. and Valsaraj, K. T.: Characterization of dissolved organic matter in fogwater by excitation-emission matrix fluorescence spectroscopy, Atmos. Environ., 44(27), 3246-3253, doi:10.1016/j.atmosenv.2010.05.055, 2010.

Bones, D. L., Henricksen, D. K., Mang, S. A., Gonsior, M., Bateman, A. P., Nguyen, T. B., Cooper, W. J. and Nizkorodov, S. A.: Appearance of strong absorbers and fluorophores in limonene-O3 secondary organic aerosol due to NH4+-mediated chemical aging over long time scales, J. Geophys. Res. Atmos., 115(5), 1-14, doi:10.1029/2009JD012864, 2010.

Boone, E. J., Laskin, A., Laskin, J., Wirth, C., Shepson, P. B., Stirm, B. H. and Pratt, K. A.: Aqueous Processing of Atmospheric Organic Particles in Cloud Water Collected via Aircraft Sampling, Environ. Sci. Technol., doi:10.1021/acs.est.5b01639, 2015.

Brown, H., Liu, X., Feng, Y., Jiang, Y., Wu, M., Lu, Z., Wu, C., Murphy, S. and Pokhrel, R.: Radiative effect and climate impacts of brown carbon with the Community Atmosphere Model (CAM5), Atmos. Chem. Phys., 18(24), 17745-17768, doi:10.5194/acp-1817745-2018, 2018.

Catalá, T. S., Reche, I., Fuentes-Lema, A., Romera-Castillo, C., Nieto-Cid, M., Ortega-Retuerta, E., Calvo, E., Álvarez, M., Marrasé, C., Stedmon, C. A. and Álvarez-Salgado, X. A.: Turnover time of fluorescent dissolved organic matter in the dark global ocean, Nat. Commun., 6(1), 5986, doi:10.1038/ncomms6986, 2015.

Chen, Q., Ikemori, F. and Mochida, M.: Light Absorption and Excitation-Emission Fluorescence of Urban Organic Aerosol Components and Their Relationship to Chemical Structure, Environ. Sci. Technol., 50(20), 10859-10868, doi:10.1021/acs.est.6b02541, 2016.

Chen, Y., Ge, X., Chen, H., Xie, X., Chen, Y., Wang, J., Ye, Z., Bao, M., Zhang, Y. and Chen, M.: Seasonal light absorption properties of water-soluble brown carbon in atmospheric fine particles in Nanjing, China, Atmos. Environ., 187(June), 230-240, doi:10.1016/j.atmosenv.2018.06.002, 2018.

Chen, Y., Xie, X., Shi, Z., Li, Y., Gai, X., Wang, J., Li, H., Wu, Y., Zhao, X., Chen, M. and Ge, X.: Brown carbon in atmospheric fine particles in Yangzhou, China: Light absorption properties and source apportionment, Atmos. Res., 244(April), doi:10.1016/j.atmosres.2020.105028, 2020.

Cheng, C., Wang, G., Meng, J., Wang, Q., Cao, J., Li, J. and Wang, J.: Size-resolved airborne particulate oxalic and related secondary organic aerosol species in the urban atmosphere of Chengdu, China, Atmos. Res., doi:10.1016/j.atmosres.2015.04.010, 2015.

Choudhary, V., Rajput, P., Singh, D. K., Singh, A. K. and Gupta, T.: Light absorption characteristics of brown carbon during foggy and non-foggy episodes over the Indo-Gangetic Plain, Atmos. Pollut. Res., 9(3), 494-501, doi:10.1016/j.apr.2017.11.012, 2018.

315 Coble, P. G.: Marine optical biogeochemistry: The chemistry of ocean color, Chem. Rev., 107(2), 402-418, doi:10.1021/cr050350+, 2007. 
Demoz, B. B., Collett, J. L. and Daube, B. C.: On the caltech active strand cloudwater collectors, Atmos. Res., 41(1), 47-62, doi:10.1016/0169-8095(95)00044-5, 1996.

Desyaterik, Y., Sun, Y., Shen, X., Lee, T., Wang, X., Wang, T. and Collett, J. L.: Speciation of "brown" carbon in cloud water impacted by agricultural biomass burning in eastern China, J. Geophys. Res. Atmos., 118(13), 7389-7399, doi:10.1002/jgrd.50561, 2013.

Drinovec, L., Močnik, G., Zotter, P., Prévôt, A. S. H., Ruckstuhl, C., Coz, E., Rupakheti, M., Sciare, J., Müller, T., Wiedensohler, A. and Hansen, A. D. A.: The "dual-spot" Aethalometer: An improved measurement of aerosol black carbon with real-time loading compensation, Atmos. Meas. Tech., 8(5), 1965-1979, doi:10.5194/amt-8-1965-2015, 2015.

Ervens, B.: Modeling the Processing of Aerosol and Trace Gases in Clouds and Fogs, Chem. Rev., 115(10), 4157-4198, doi:10.1021/cr5005887, 2015.

Fan, X., Wei, S., Zhu, M., Song, J. and Peng, P.: Comprehensive characterization of humic-like substances in smoke PM2.5 emitted from the combustion of biomass materials and fossil fuels, Atmos. Chem. Phys., 16(20), 13321-13340, doi:10.5194/acp-16-13321-2016, 2016.

Fu, Y., Lin, Q., Zhang, G., Yang, Y., Yang, Y., Lian, X., Peng, L., Jiang, F., Bi, X., Li, L., Wang, Y., Chen, D., Ou, J., Wang, X., Zhu, J. and Sheng, G.: Impact of in-cloud aqueous processes on the chemical compositions and morphology of individual atmospheric aerosols, Atmos. Chem. Phys., 20(22), 14063-14075, doi:10.5194/acp-20-14063-2020, 2020.

Gao, Y., Wang, Q., Li, L., Dai, W., Yu, J., Ding, L., Li, J., Xin, B., Ran, W., Han, Y. and Cao, J.: Optical properties of mountain primary and secondary brown carbon aerosols in summertime, Sci. Total Environ., 806, doi:10.1016/j.scitotenv.2021.150570, 2022.

Gelencsér, A., Hoffer, A., Kiss, G., Tombácz, E., Kurdi, R. and Bencze, L.: In-situ formation of light-absorbing organic matter in cloud water, J. Atmos. Chem., 45(1), 25-33, doi:10.1023/A:1024060428172, 2003.

Gilardoni, S., Massoli, P., Paglione, M., Giulianelli, L., Carbone, C., Rinaldi, M., Decesari, S., Sandrini, S., Costabile, F., Gobbi, G. P., Pietrogrande, M. C., Visentin, M., Scotto, F., Fuzzi, S. and Facchini, M. C.: Direct observation of aqueous secondary organic aerosol from biomass-burning emissions, Proc. Natl. Acad. Sci. U. S. A., doi:10.1073/pnas.1602212113, 2016.

De Haan, D. O., Hawkins, L. N., Kononenko, J. A., Turley, J. J., Corrigan, A. L., Tolbert, M. A. and Jimenez, J. L.: Formation of nitrogencontaining oligomers by methylglyoxal and amines in simulated evaporating cloud droplets, Environ. Sci. Technol., 45(3), 984-991, doi:10.1021/es102933x, 2011.

Hawkins, L. N., Lemire, A. N., Galloway, M. M., Corrigan, A. L., Turley, J. J., Espelien, B. M. and De Haan, D. O.: Maillard Chemistry in Clouds and Aqueous Aerosol As a Source of Atmospheric Humic-Like Substances, Environ. Sci. Technol., 50(14), 7443-7452, doi:10.1021/acs.est.6b00909, 2016.

Heal, M. R., Harrison, M. A. J. and Neil Cape, J.: Aqueous-phase nitration of phenol by N2O5 and ClNO2, Atmos. Environ., doi:10.1016/j.atmosenv.2007.02.003, 2007.

Hecobian, A., Zhang, X., Zheng, M., Frank, N., Edgerton, E. S. and Weber, R. J.: Water-soluble organic aerosol material and the lightabsorption characteristics of aqueous extracts measured over the Southeastern United States, Atmos. Chem. Phys., 10(13), 59655977, doi:10.5194/acp-10-5965-2010, 2010.

Hems, R. F., Schnitzler, E. G., Liu-Kang, C., Cappa, C. D. and Abbatt, J. P. D.: Aging of Atmospheric Brown Carbon Aerosol, ACS Earth Sp. Chem., 5(4), 722-748, doi:10.1021/acsearthspacechem.0c00346, 2021.

Huang, R. J., Yang, L., Shen, J., Yuan, W., Gong, Y., Guo, J., Cao, W., Duan, J., Ni, H., Zhu, C., Dai, W., Li, Y., Chen, Y., Chen, Q., Wu, Y., Zhang, R., Dusek, U., O’Dowd, C. and Hoffmann, T.: Water-Insoluble Organics Dominate Brown Carbon in Wintertime Urban 
Aerosol of China: Chemical Characteristics and Optical Properties, Environ. Sci. Technol., 54(13), 7836-7847, doi:10.1021/acs.est.0c01149, 2020.

Huguet, A., Vacher, L., Relexans, S., Saubusse, S., Froidefond, J. M. and Parlanti, E.: Properties of fluorescent dissolved organic matter in the Gironde Estuary, Org. Geochem., 40(6), 706-719, doi:10.1016/j.orggeochem.2009.03.002, 2009.

Kaskaoutis, D. G., Grivas, G., Stavroulas, I., Bougiatioti, A., Liakakou, E., Dumka, U. C., Gerasopoulos, E. and Mihalopoulos, N.: Apportionment of black and brown carbon spectral absorption sources in the urban environment of Athens, Greece, during winter, Sci. Total Environ., 801, 149739, doi:10.1016/j.scitotenv.2021.149739, 2021.

Kaur, R. and Anastasio, C.: Light absorption and the photoformation of hydroxyl radical and singlet oxygen in fog waters, Atmos. Environ., 164, 387-397, doi:10.1016/j.atmosenv.2017.06.006, 2017.

Kim, H., Kim, J. Y., Jin, H. C., Lee, J. Y. and Lee, S. P.: Seasonal variations in the light-absorbing properties of water-soluble and insoluble organic aerosols in Seoul, Korea, Atmos. Environ., 129, 234-242, doi:10.1016/j.atmosenv.2016.01.042, 2016.

Kim, H., Collier, S., Ge, X., Xu, J., Sun, Y., Jiang, W., Wang, Y., Herckes, P. and Zhang, Q.: Chemical processing of water-soluble species and formation of secondary organic aerosol in fogs, Atmos. Environ., doi:10.1016/j.atmosenv.2018.11.062, 2019.

Kirillova, E. N., Marinoni, A., Bonasoni, P., Vuillermoz, E., Facchini, M. C., Fuzzi, S. and Decesari, S.: Light absorption properties of brown carbon in the high Himalayas, J. Geophys. Res., doi:10.1002/2016JD025030, 2016.

Kristensen, T. B., Du, L., Nguyen, Q. T., Nøjgaard, J. K., Bender Koch, C., Faurskov Nielsen, O., Hallar, A. G., Lowenthal, D. H., Nekat, B., Van Pinxteren, D., Herrmann, H., Glasius, M., Kjaergaard, H. G. and Bilde, M.: Chemical properties of HULIS from three different environments, J. Atmos. Chem., doi:10.1007/s10874-015-9302-8, 2015.

Kristensson, A., Rosenørn, T. and Bilde, M.: Cloud droplet activation of amino acid aerosol particles, J. Phys. Chem. A, doi:10.1021/jp9055329, 2010.

Lawaetz, A. J. and Stedmon, C. A.: Fluorescence intensity calibration using the Raman scatter peak of water, Appl. Spectrosc., 63(8), 936940, doi:10.1366/000370209788964548, 2009.

Lebedev, A. T., Polyakova, O. V., Mazur, D. M., Artaev, V. B., Canet, I., Lallement, A., Vaïtilingom, M., Deguillaume, L. and Delort, A. M.: Detection of semi-volatile compounds in cloud waters by GC $\times$ GC-TOF-MS. Evidence of phenols and phthalates as priority pollutants, Environ. Pollut., doi:10.1016/j.envpol.2018.05.089, 2018.

Li, M., Fan, X., Zhu, M., Zou, C., Song, J., Wei, S., Jia, W. and Peng, P.: Abundance and Light Absorption Properties of Brown Carbon Emitted from Residential Coal Combustion in China, Environ. Sci. Technol., 53(2), 595-603, doi:10.1021/acs.est.8b05630, 2019.

Lian, X., Zhang, G., Yang, Y., Lin, Q., Fu, Y., Jiang, F., Peng, L., Hu, X., Chen, D., Wang, X., Peng, P., Sheng, G. and Bi, X.: Evidence for the Formation of Imidazole from Carbonyls and Reduced Nitrogen Species at the Individual Particle Level in the Ambient Atmosphere, Environ. Sci. Technol. Lett., doi:10.1021/acs.estlett.0c00722, 2021.

Lin, G., Penner, J. E., Flanner, M. G., Sillman, S., Xu, L. and Zhou, C.: Radiative forcing of organic aerosol in the atmosphere and on snow: Effects of SOA and brown carbon, J. Geophys. Res., doi:10.1002/2013JD021186, 2014a.

Lin, Q., Zhang, G., Peng, L., Bi, X., Wang, X., Brechtel, F. J., Li, M., Chen, D., Peng, P., Sheng, G. and Zhou, Z.: In situ chemical composition measurement of individual cloud residue particles at a mountain site, southern China, Atmos. Chem. Phys., 17(13), 8473-8488, doi:10.5194/acp-17-8473-2017, 2017.

Lin, Y. C., Zhang, Y. L., Xie, F., Fan, M. Y. and Liu, X.: Substantial decreases of light absorption, concentrations and relative contributions of fossil fuel to light-absorbing carbonaceous aerosols attributed to the COVID-19 lockdown in east China, Environ. Pollut., doi:10.1016/j.envpol.2021.116615, 2021. 
Lin, Y. H., Budisulistiorini, S. H., Chu, K., Siejack, R. A., Zhang, H., Riva, M., Zhang, Z., Gold, A., Kautzman, K. E. and Surratt, J. D.: Light-absorbing oligomer formation in secondary organic aerosol from reactive uptake of isoprene epoxydiols, Environ. Sci. Technol., doi:10.1021/es503142b, 2014b.

Liu, D., He, C., Schwarz, J. P. and Wang, X.: Lifecycle of light-absorbing carbonaceous aerosols in the atmosphere, npj Clim. Atmos. Sci., 3(1), doi:10.1038/s41612-020-00145-8, 2020.

Liu, J., Horowitz, L. W., Fan, S., Carlton, A. G. and Levy, H.: Global in-cloud production of secondary organic aerosols: Implementation of a detailed chemical mechanism in the GFDL atmospheric model AM3, J. Geophys. Res. Atmos., doi:10.1029/2012JD017838, 2012.

Lüttke, J. and Levsen, K.: Phase partitioning of phenol and nitrophenols in clouds, Atmos. Environ., doi:10.1016/S1352-2310(96)00228-2, 1997.

McKnight, D. M., Boyer, E. W., Westerhoff, P. K., Doran, P. T., Kulbe, T. and Andersen, D. T.: Spectrofluorometric characterization of dissolved organic matter for indication of precursor organic material and aromaticity, Limnol. Oceanogr., doi:10.4319/1o.2001.46.1.0038, 2001.

Murphy, K. R., Stedmon, C. A., Graeber, D. and Bro, R.: Fluorescence spectroscopy and multi-way techniques. PARAFAC, Anal. Methods, 5(23), 6557-6566, doi:10.1039/c3ay41160e, 2013.

Nguyen, T. B., Lee, P. B., Updyke, K. M., Bones, D. L., Laskin, J., Laskin, A. and Nizkorodov, S. A.: Formation of nitrogen- and sulfurcontaining light-absorbing compounds accelerated by evaporation of water from secondary organic aerosols, J. Geophys. Res. Atmos., 117(1), 1-14, doi:10.1029/2011JD016944, 2012.

Pang, H., Zhang, Q., Lu, X., Li, K., Chen, H., Chen, J., Yang, X., Ma, Y., Ma, J. and Huang, C.: Nitrite-Mediated Photooxidation of Vanillin in the Atmospheric Aqueous Phase, Environ. Sci. Technol., doi:10.1021/acs.est.9b03649, 2019.

Park, S. S. and Yu, J.: Chemical and light absorption properties of humic-like substances from biomass burning emissions under controlled combustion experiments, Atmos. Environ., doi:10.1016/j.atmosenv.2016.04.022, 2016.

Perrino, C. and Marcovecchio, F.: A new method for assessing the contribution of Primary Biological Atmospheric Particles to the mass concentration of the atmospheric aerosol, Environ. Int., doi:10.1016/j.envint.2015.11.015, 2016.

Pósfai, M., Gelencsér, A., Simonics, R., Arató, K., Li, J., Hobbs, P. V. and Buseck, P. R.: Atmospheric tar balls: Particles from biomass and biofuel burning, J. Geophys. Res. Atmos., doi:10.1029/2003jd004169, 2004.

Pratt, K. A., Fiddler, M. N., Shepson, P. B., Carlton, A. G. and Surratt, J. D.: Organosulfates in cloud water above the Ozarks' isoprene source region, Atmos. Environ., doi:10.1016/j.atmosenv.2013.05.011, 2013.

Saleh, R.: From Measurements to Models: Toward Accurate Representation of Brown Carbon in Climate Calculations, Curr. Pollut. Reports, 6(2), 90-104, doi:10.1007/s40726-020-00139-3, 2020.

Saleh, R., Robinson, E. S., Tkacik, D. S., Ahern, A. T., Liu, S., Aiken, A. C., Sullivan, R. C., Presto, A. A., Dubey, M. K., Yokelson, R. J., Donahue, N. M. and Robinson, A. L.: Brownness of organics in aerosols from biomass burning linked to their black carbon content, Nat. Geosci., 7(9), 647-650, doi:10.1038/ngeo2220, 2014.

Satish, R., Rastogi, N., Singh, A. and Singh, D.: Change in characteristics of water-soluble and water-insoluble brown carbon aerosols during a large-scale biomass burning, Environ. Sci. Pollut. Res., 27(26), 33339-33350, doi:10.1007/s11356-020-09388-7, 2020.

Seinfeld, J. H. and Pandis, S. N.: Atmospheric Chemistry and Physics: From Air Pollution to Climate Change, John Wiley \& Sons., 2016.

Shapiro, E. L., Szprengiel, J., Sareen, N., Jen, C. N., Giordano, M. R. and McNeill, V. F.: Light-absorbing secondary organic material formed by glyoxal in aqueous aerosol mimics, Atmos. Chem. Phys., doi:10.5194/acp-9-2289-2009, 2009. 
Shingler, T., Dey, S., Sorooshian, A., Brechtel, F. J., Wang, Z., Metcalf, A., Coggon, M., Mülmenstädt, J., Russell, L. M., Jonsson, H. H. and Seinfeld, J. H.: Characterisation and airborne deployment of a new counterflow virtual impactor inlet, Atmos. Meas. Tech., 5(6), 1259-1269, doi:10.5194/amt-5-1259-2012, 2012.

Soleimanian, E., Mousavi, A., Taghvaee, S., Shafer, M. M. and Sioutas, C.: Impact of secondary and primary particulate matter (PM) sources on the enhanced light absorption by brown carbon $(\mathrm{BrC})$ particles in central Los Angeles, Sci. Total Environ., 705, 135902, doi:10.1016/j.scitotenv.2019.135902, 2020.

Spracklen, D. V., Jimenez, J. L., Carslaw, K. S., Worsnop, D. R., Evans, M. J., Mann, G. W., Zhang, Q., Canagaratna, M. R., Allan, J., Coe, H., McFiggans, G., Rap, A. and Forster, P.: Aerosol mass spectrometer constraint on the global secondary organic aerosol budget, Atmos. Chem. Phys., 11(23), 12109-12136, doi:10.5194/acp-11-12109-2011, 2011.

Vione, D., Maurino, V., Minero, C. and Pelizzetti, E.: Phenol photonitration upon UV irradiation of nitrite in aqueous solution I: Effects of oxygen and 2-propanol, Chemosphere, doi:10.1016/S0045-6535(01)00035-2, 2001.

Wang, G., Kawamura, K., Cheng, C., Li, J., Cao, J., Zhang, R., Zhang, T., Liu, S. and Zhao, Z.: Molecular distribution and stable carbon isotopic composition of dicarboxylic acids, ketocarboxylic acids, and $\alpha$-dicarbonyls in size-resolved atmospheric particles from Xi'an City, China, Environ. Sci. Technol., doi:10.1021/es204322c, 2012.

Wang, H., Zhang, L., Huo, T., Wang, B., Yang, F., Chen, Y., Tian, M., Qiao, B. and Peng, C.: Application of parallel factor analysis model to decompose excitation-emission matrix fluorescence spectra for characterizing sources of water-soluble brown carbon in PM2.5, Atmos. Environ., doi:10.1016/j.atmosenv.2019.117192, 2020a.

Wang, Q., Han, Y., Ye, J., Liu, S., Pongpiachan, S., Zhang, N., Han, Y., Tian, J., Wu, C., Long, X., Zhang, Q., Zhang, W., Zhao, Z. and Cao, J.: High Contribution of Secondary Brown Carbon to Aerosol Light Absorption in the Southeastern Margin of Tibetan Plateau, Geophys. Res. Lett., 46(9), 4962-4970, doi:10.1029/2019GL082731, 2019a.

Wang, Q., Ye, J., Wang, Y., Zhang, T., Ran, W., Wu, Y., Tian, J., Li, L., Zhou, Y., Hang Ho, S. S., Dang, B., Zhang, Q., Zhang, R., Chen, Y., Zhu, C. and Cao, J.: Wintertime Optical Properties of Primary and Secondary Brown Carbon at a Regional Site in the North China Plain, Environ. Sci. Technol., 53(21), 12389-12397, doi:10.1021/acs.est.9b03406, 2019b.

Wang, Q., Liu, H., Wang, P., Dai, W., Zhang, T., Zhao, Y., Tian, J., Zhang, W., Han, Y. and Cao, J.: Optical source apportionment and radiative effect of light-absorbing carbonaceous aerosols in a tropical marine monsoon climate zone: The importance of ship emissions, Atmos. Chem. Phys., 20(24), 15537-15549, doi:10.5194/acp-20-15537-2020, 2020 b.

Wang, Q., Wang, L., Tao, M., Chen, N., Lei, Y., Sun, Y., Xin, J., Li, T., Zhou, J., Liu, J., Ji, D. and Wang, Y.: Exploring the variation of black and brown carbon during COVID-19 lockdown in megacity Wuhan and its surrounding cities, China, Sci. Total Environ., 791, 148226, doi:10.1016/j.scitotenv.2021.148226, 2021.

Weishaar, J. L., Aiken, G. R., Bergamaschi, B. A., Fram, M. S., Fujii, R. and Mopper, K.: Evaluation of specific ultraviolet absorbance as an indicator of the chemical composition and reactivity of dissolved organic carbon, Environ. Sci. Technol., 37(20), 4702-4708, doi:10.1021/es030360x, 2003.

Wu, C. and Yu, J. Z.: Determination of primary combustion source organic carbon-to-elemental carbon (OC / EC) ratio using ambient OC and EC measurements: Secondary OC-EC correlation minimization method, Atmos. Chem. Phys., 16(8), 5453-5465, doi:10.5194/acp-16-5453-2016, 2016.

Wu, C., Wu, D. and Zhen Yu, J.: Quantifying black carbon light absorption enhancement with a novel statistical approach, Atmos. Chem. Phys., 18(1), 289-309, doi:10.5194/acp-18-289-2018, 2018. 
Wu, G., Ram, K., Fu, P., Wang, W., Zhang, Y., Liu, X., Stone, E. A., Pradhan, B. B., Dangol, P. M., Panday, A. K., Wan, X., Bai, Z., Kang, S., Zhang, Q. and Cong, Z.: Water-Soluble Brown Carbon in Atmospheric Aerosols from Godavari (Nepal), a Regional Representative of South Asia, Environ. Sci. Technol., 53(7), 3471-3479, doi:10.1021/acs.est.9b00596, 2019.

Yang, J., Au, W. C., Law, H., Lam, C. H. and Nah, T.: Formation and evolution of brown carbon during aqueous-phase nitrate-mediated photooxidation of guaiacol and 5-nitroguaiacol, Atmos. Environ., doi:10.1016/j.atmosenv.2021.118401, 2021a.

Yang, Y., Lin, Q., Fu, Y., Lian, X., Jiang, F., Peng, L., Zhang, G., Li, L., Chen, D., Li, M., Ou, J., Bi, X., Wang, X. and Sheng, G.: Stageresolved in-cloud scavenging of submicron and BC-containing particles: A case study, Atmos. Environ., 244(February 2020), 117883, doi:10.1016/j.atmosenv.2020.117883, 2021b.

Zhang, G., Lin, Q., Peng, L., Bi, X., Chen, D., Li, M., Li, L., Brechtel, F. J., Chen, J., Yan, W., Wang, X., Peng, P., Sheng, G. and Zhou, Z.: The single-particle mixing state and cloud scavenging of black carbon: A case study at a high-altitude mountain site in southern China, Atmos. Chem. Phys., 17(24), 14975-14985, doi:10.5194/acp-17-14975-2017, 2017a.

Zhang, G., Lin, Q., Peng, L., Yang, Y., Fu, Y., Bi, X., Li, M., Chen, D., Chen, J., Cai, Z., Wang, X., Peng, P., Sheng, G. and Zhou, Z.: Insight into the in-cloud formation of oxalate based on in situ measurement by single particle mass spectrometry, Atmos. Chem. Phys., 17(22), 13891-13901, doi:10.5194/acp-17-13891-2017, 2017b

Zhang, Q. and Anastasio, C.: Free and combined amino compounds in atmospheric fine particles (PM2.5) and fog waters from Northern California, Atmos. Environ., 37(16), 2247-2258, doi:10.1016/S1352-2310(03)00127-4, 2003.

Zhang, Q., Shen, Z., Zhang, L., Zeng, Y., Ning, Z., Zhang, T., Lei, Y., Wang, Q., Li, G., Sun, J., Westerdahl, D., Xu, H. and Cao, J.: Investigation of Primary and Secondary Particulate Brown Carbon in Two Chinese Cities of Xi' an and Hong Kong in Wintertime, Environ. Sci. Technol., 54(7), 3803-3813, doi:10.1021/acs.est.9b05332, 2020.

Zhang, Q., Shen, Z., Zhang, T., Kong, S., Lei, Y., Wang, Q., Tao, J., Zhang, R., Wei, P., Wei, C., Cui, S., Cheng, T., Ho, S. S. H., Li, Z., $\mathrm{Xu}, \mathrm{H}$. and Cao, J.: Spatial distribution and sources of winter black carbon and brown carbon in six Chinese megacities, Sci. Total Environ., doi:10.1016/j.scitotenv.2020.143075, 2021.

Zhang, Y., Forrister, H., Liu, J., DIbb, J., Anderson, B., Schwarz, J. P., Perring, A. E., Jimenez, J. L., Campuzano-Jost, P., Wang, Y., Nenes, A. and Weber, R. J.: Top-of-atmosphere radiative forcing affected by brown carbon in the upper troposphere, Nat. Geosci., 10(7), 486-489, doi:10.1038/ngeo2960, 2017c.

Zhao, W., Fu, P., Yue, S., Li, L., Xie, Q., Zhu, C., Wei, L., Ren, H., Li, P., Li, W., Sun, Y., Wang, Z., Kawamura, K. and Chen, J.: Excitation-emission matrix fluorescence, molecular characterization and compound-specific stable carbon isotopic composition of dissolved organic matter in cloud water over Mt. Tai, Atmos. Environ., 213(December 2018), 608-619, doi:10.1016/j.atmosenv.2019.06.034, 2019.

Zhu, C. S., Qu, Y., Huang, H., Chen, J., Dai, W. T., Huang, R. J. and Cao, J. J.: Black Carbon and Secondary Brown Carbon, the Dominant Light Absorption and Direct Radiative Forcing Contributors of the Atmospheric Aerosols Over the Tibetan Plateau, Geophys. Res. Lett., 48(11), 1-9, doi:10.1029/2021GL092524, 2021.

Zhuang, B. L., Liu, L., Shen, F. H., Wang, T. J. and Han, Y.: Semidirect radiative forcing of internal mixed black carbon cloud droplet and its regional climatic effect over China, J. Geophys. Res. Atmos., 115(18), 1-20, doi:10.1029/2009JD013165, 2010. dissolved organic matter in soils subjected to drying, Chemosphere, doi:10.1016/S0045-6535(98)00166-0, 1999. 

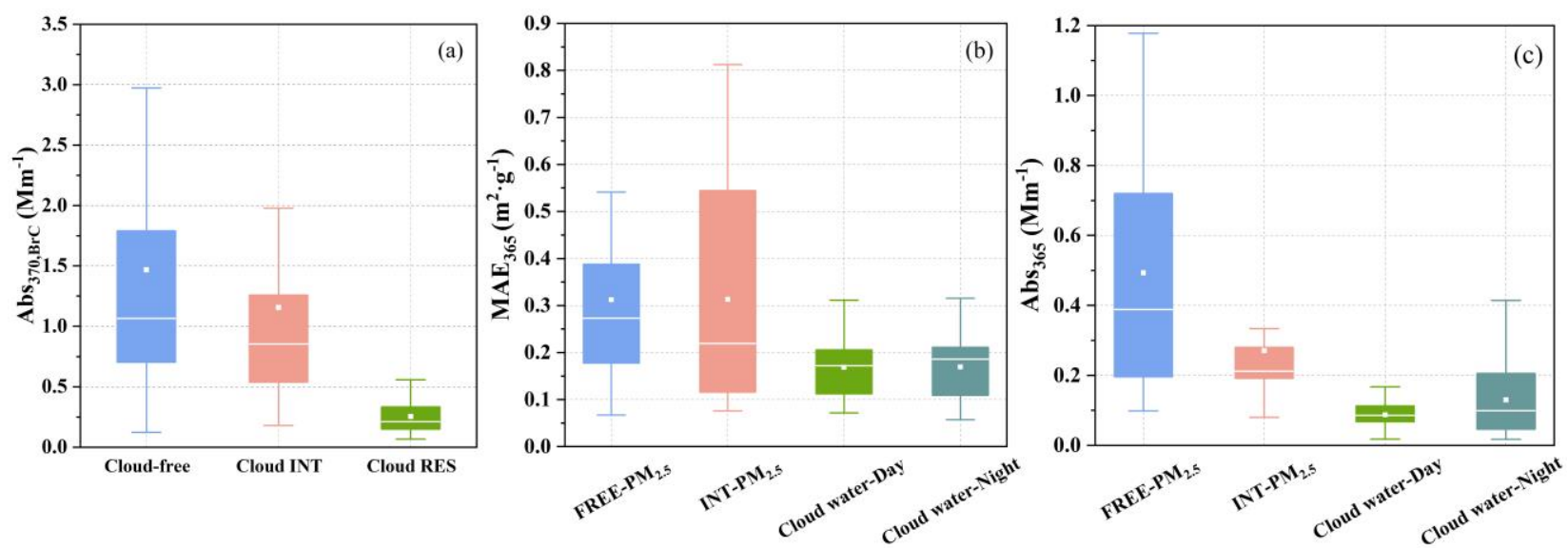

Fig. 1. (a) The Abs370 of cloud-free, cloud INT, and cloud RES particles, and (b) the MAE 365 and (c) Abs3650f FREE-PM2.5, INTPM2.5, cloud water-Day, and cloud water-Night. 

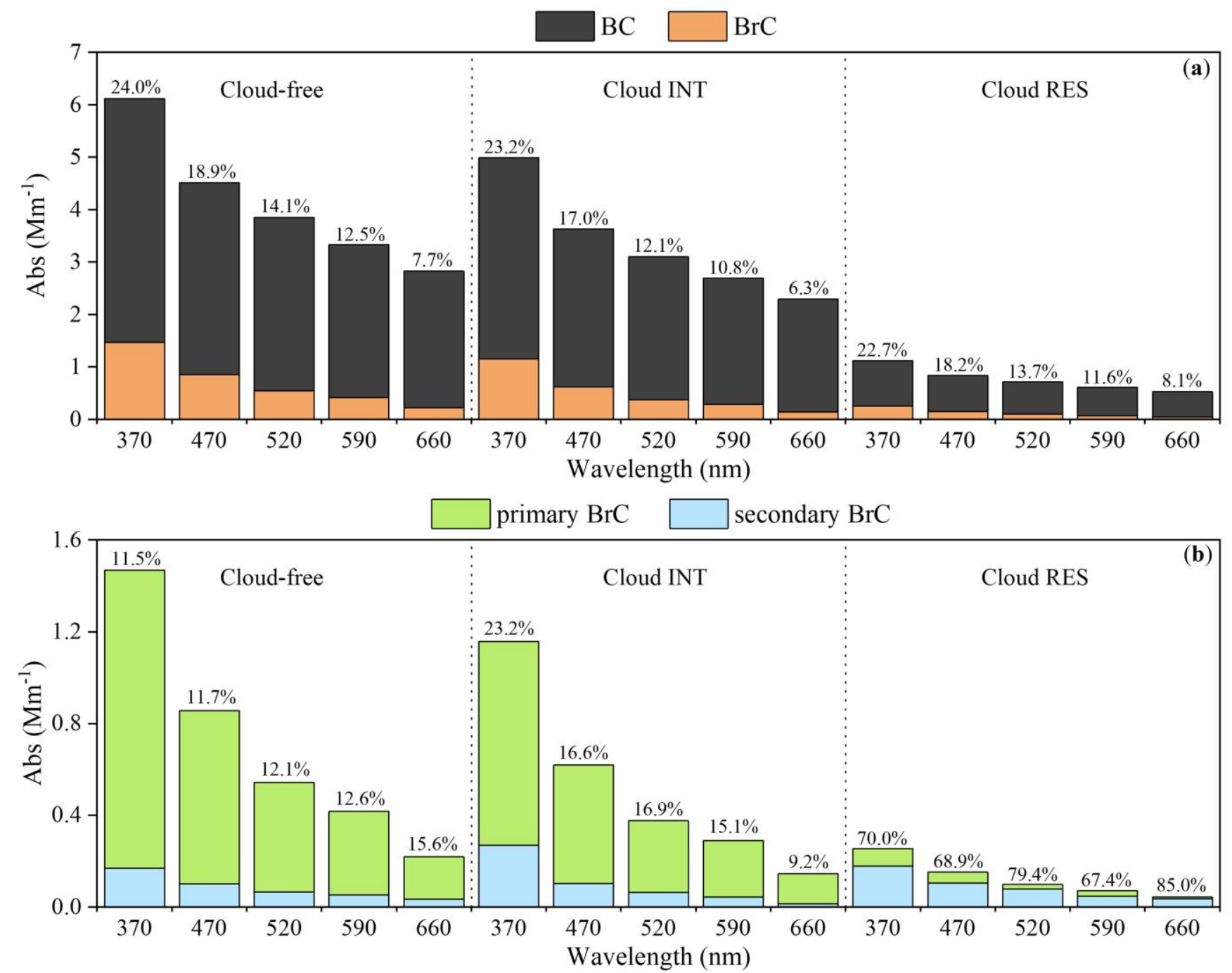

Fig. 2. The light-absorption of (a) $\mathrm{BrC}$ and $\mathrm{BC}$; (b) primary $\mathrm{BrC}$ and secondary $\mathrm{BrC}$ at different wavelengths, and the percentage represent the contribution of (a) BrC light-absorption to the total particle light-absorption; (b) secondary BrC light-absorption to the total BrC light-absorption in the cloud-free, cloud INT, and cloud RES particles, respectively. 

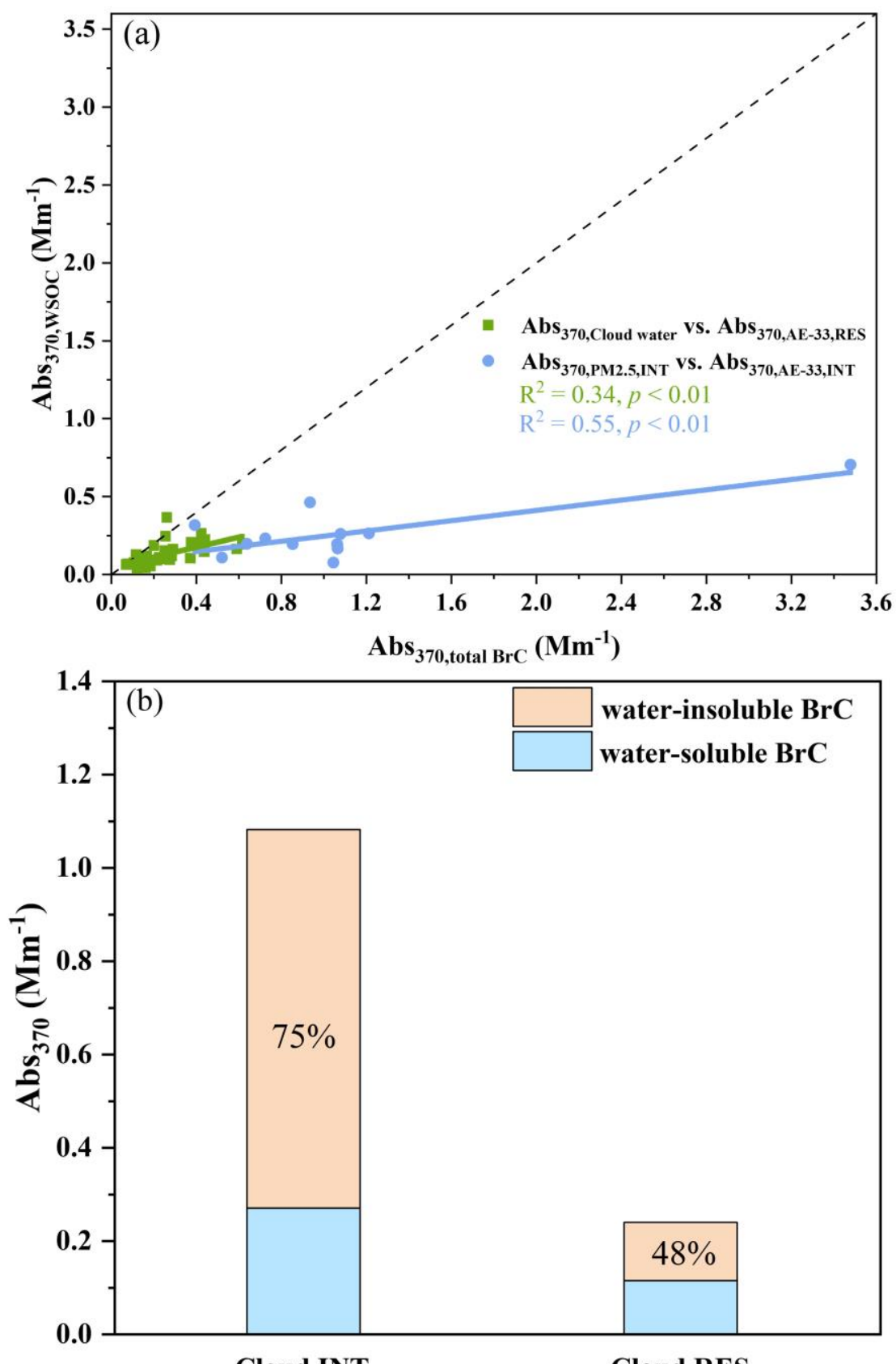

Fig. 3. (a) The correlations of WSOC light-absorption to total $\mathrm{BrC}$ light-absorption in $370 \mathrm{~nm}$, and (b) the contribution of watersoluble $\mathrm{BrC}$ and water-insoluble $\mathrm{BrC}$ to total $\mathrm{BrC}$ light-absorption. 

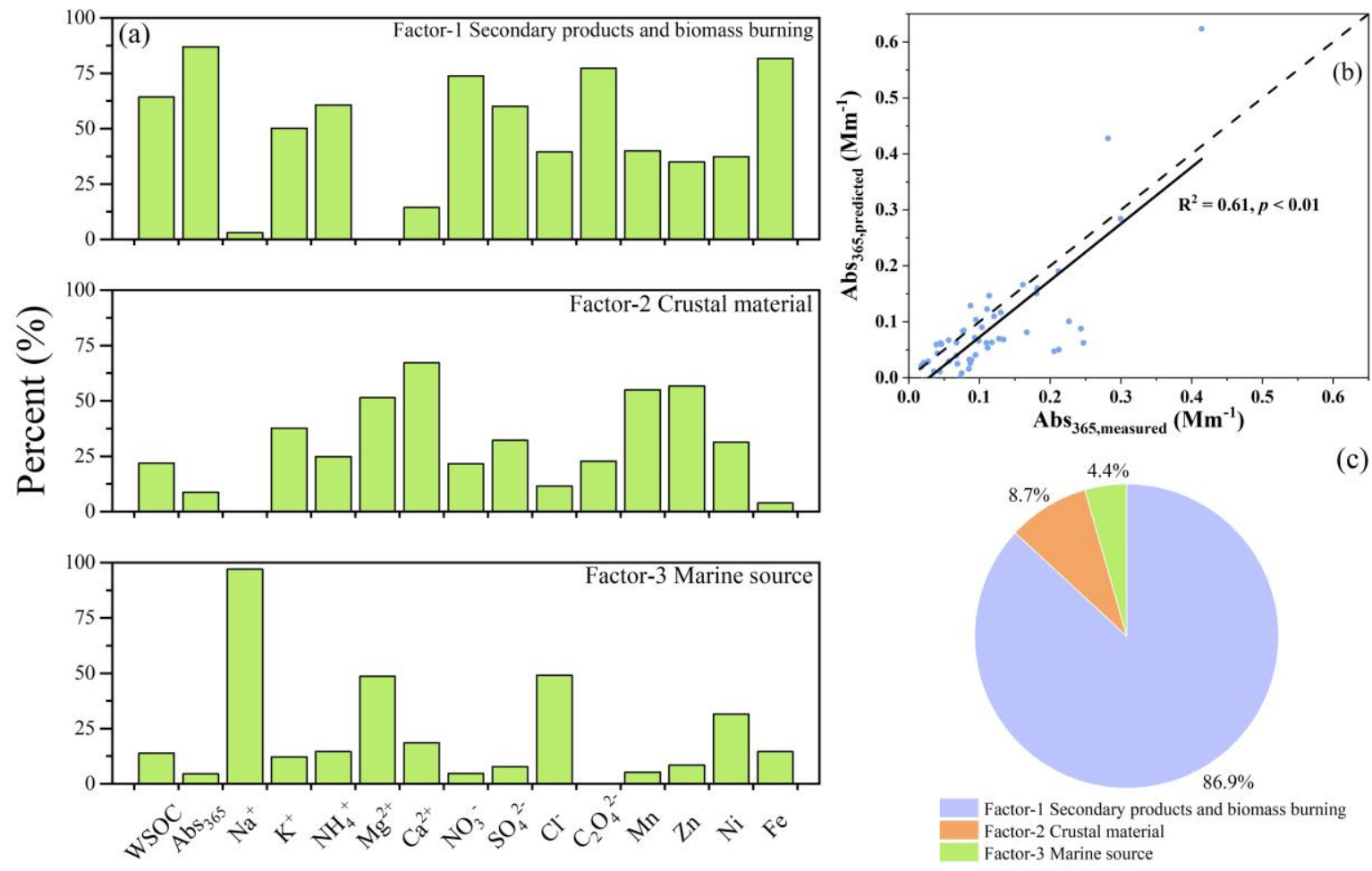

Fig. 4. (a) The composition profiles (\% of each species) for the three factors simulated of cloud water by PMF, and (b) the correlation of measured, and predicated $\mathrm{Abs}_{365}$, and (c) the source apportionment for $\mathrm{Abs}_{365}$ in cloud water. 

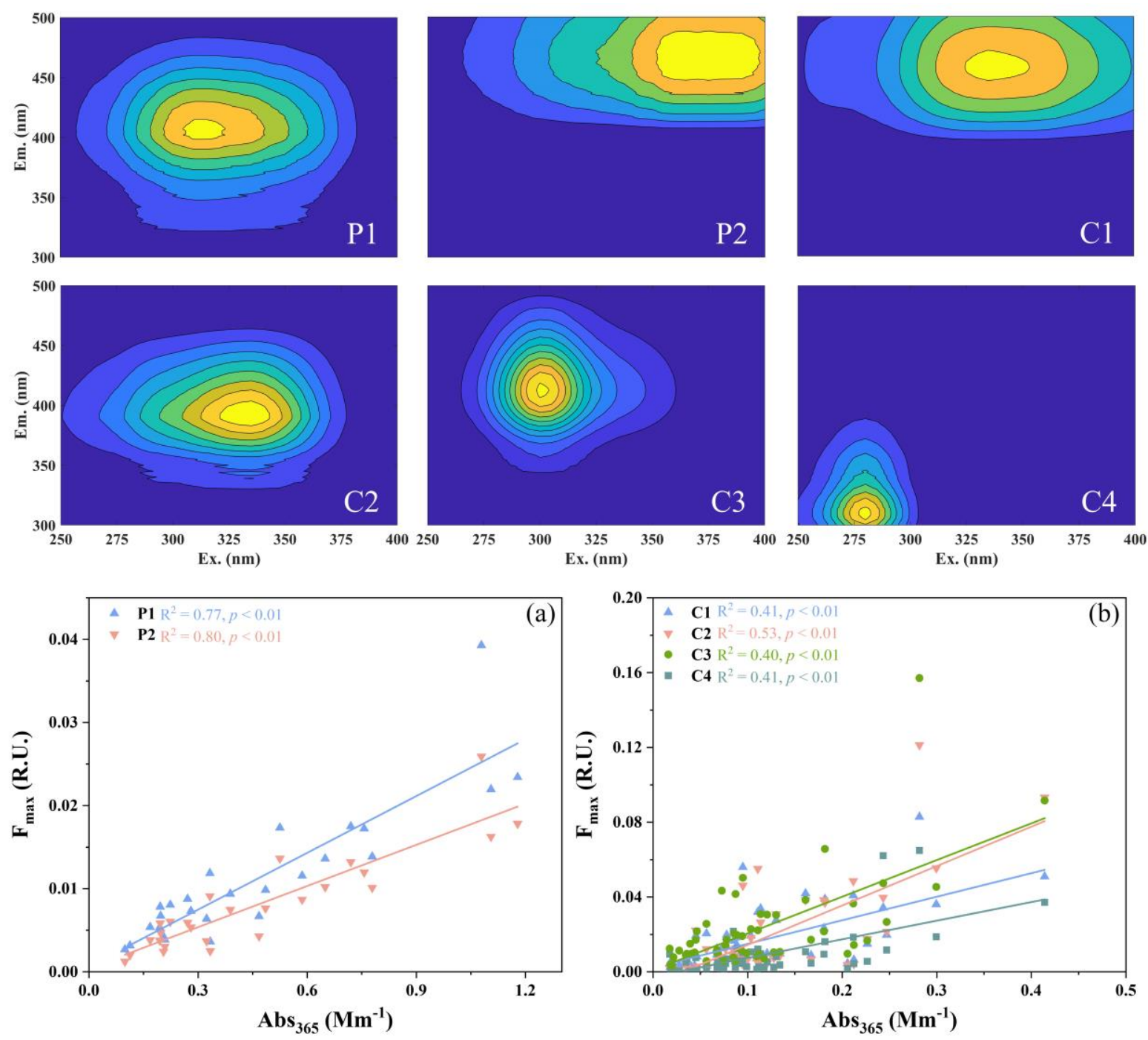

Fig. 5. The EEMs components in $\mathrm{PM}_{2.5}$ (P1-P2) and cloud water (C1-C4) that were identified by PARAFAC model, and the correlation between each chromophore $F_{\max }$ and $\mathrm{Abs}_{365}$ in (a) $\mathbf{P M}_{2.5}$, and (b) cloud water. 